\title{
HUBUNGAN TINGKAT PENGETAHUAN PERAWAT DALAM MELAKSANAKAN BUDAYA KESELAMATAN PASIEN DI RUANG RAWAT INAP
}

\author{
SELLY FEBI MARGARETHA PANGGABEAN \\ sellyfebi2601@gmail.com
}

\section{LATAR BELAKANG}

Keselamatan pasien merupakan suatu sistem yang membuat asuhan pasien lebih aman, meliputi asesmen risiko, indentifikasi dan pengelolaan risiko pasien, pelaporan dan analisis insiden, kemampuan belajar dari insiden dan tindak lanjutnya, serta implementasi solusi untuk meminimalkan timbulnya risiko dan mencegah terjadinya cedera yang disebabkan oleh kesalahan akibat melaksanakan suatu tindakan atau tidak mengambil tindakan yang seharusnya diambil (PMK No 11,2017). Keselamatan pasien di rumah sakit melibatkan partisipasi dari semua petugas kesehatan, terutama perawat. Perawat sebagai salah satu tenaga kesehatan yang mempunyai jumlah cukup dominan di rumah sakit yaitu sebesar $50 \%$ sampai $60 \%$ dari jumlah tenaga kesehatan yang ada. Pelayanan asuhan keperawatan yang diberikan kepada pasien merupakan pelayanan yang terintegrasi dari pelayanan kesehatan yang lainnya dan memiliki peran yang cukup penting bagi terwujudnya kesehatan dan keselamatan pasien.

Budaya keselamatan pasien adalah pola terpadu perilaku individu dan organisasi dalam memberikan pelayanan yang aman dan bebas dari cedera. Budaya keselamatan adalah output dari individu dan kelompok terhadap nilai - nilai, sikap, kompetensi, dan pola kebiasaan yang mencerminkan komitmen dan gaya, serta kemampuan organisasi dan menejemen keselamatan kesehatan. Budaya keselamatan pasien merupakan suatu hal yang penting karena membangun budaya keselamatan pasien ialah suatu cara untuk membangun program keselamatan pasien secara keseluruhan, karena apabila kita lebih fokus pada budaya keselamatan pasien maka akan lebih menghasilkan hasil keselamatan yang lebih apabila dibandingkan hanya memfokuskan 
pada programnya saja. Teori Reason menyatakan bahwa insiden keselamatan pasien disebabkan oleh dua faktor, kesalahan laten dan kesalahan aktif. Keselahan laten terkait dengan insiden keselamatan pasien meliputi ; lingkungan eksternal, manajemen lingkungan sosial dan organisasi, lingkungan fisik, interaksi antara manusia dan sistem. Budaya keselamatan adalah bagian dari kesalahan laten yang terkait dengan manajemen, sedangkan indikator budaya keselamatan meliputi kerja sama, komunikasi, kepemimpinan, pelaporan dan respon terhadap kesalahan tidak menghukum. Kunci pencegahan cedera dalam pelayanan keperawatan indentifikasi risiko. Hal ini sangat tergantung pada budaya kepercayaan, kejujuran, integritas, dan keterbukaan berkomunikasi dalam sistem asuhan keperawatan.

Dalam lingkup keselamatan pasien pengetahuan perawat merupakan hal yang berhubungan dengan komitmen yang sangat diperlukan dalam upaya membangun budaya keselamatan pasien (Wijaya et al., 2016). Seorang perawat dalam memberikan asuhan keperawatan harus memiliki pengetahuan yang benar, keterampilan, dan sikap untuk menangani kompleksitas perawatan kesehatan. Tanpa pengetahuan yang memadai, tenaga kesehatan termasuk perawat tidak bisa menerapkan dan mempertahankan budaya keselamatan pasien (Myers, 2012). Dengan demikian dapat dijelaskan bahwa semakin tinggi pengetahuan perawat tentang penerapan budaya keselamatan pasien, diharapkan semakin tinggi pula perawat dalam memahami pentingnya budaya penerapan keselamatan pasien yang diberikan kepada pasien dalam pelayanan keperawatan.

\section{METODE}

Dalam kajian ini, metode yang digunakan adalah metode kualitatif, maksudnya ialah dengan cara mengumpulkan sebanyak - banyaknya data untuk dibaca,dianalisis,dan disimpulkan. Yaitu dengan literature review ini dengan menganalisis yang berfokus tentang hubungan tingkat pengetahuan perawat dalam melaksanakan budaya keselamatan pasien di ruang rawat inap. Adapun tinjauan literature review yang digunakan kajian jurnal online, textbook, ebook, dan buku pedoman yang berkaitan dengan judul kajian tersebut. Dengan menggunakan

jurnal dan referensi yang digunakan pada literature review ini dengan tahun terbit paling lama tahun 2012, dengan jumlah minimal 10 referensi literature. 


\section{HASIL}

Berdasarkan hasil analisis yang dapat disimpulkan dari jurnal - jurnal online, didapati beberapa faktor yang mempengaruhi hubungan tingkat pengetahuan perawat dalam melakukan budaya keselamatan pasien di ruang rawat inap. Adapun beberapa jurnal yang telah dibaca, dianalisis terkait judul kajian diatas yaitu :

Jurnal Pertama, Hubungan Tingkat Pengetahuan Perawat tentang Identifikasi dalam Patient Safety dengan Pelaksanaannya di Ruang Rawat Inap RSUD SK. Lerik Kupang. Jurnal Ilmiah Keperawatan Stikes Hang Tuah Surabaya Vol.14 No.2 October 2019. Menurut hasil dari jurnal tersebut, dapat disimpulkan bahwa hubungan tingkat pengetahuan perawat dengan pelaksanaan identifikasi dalam patient safety didapatkan data bahwa dari 64 responden hampir seluruhnya yang memiliki tingkat pengetahuan yang cukup baik dan pelaksanaan dalam identifikasi patient safety cukup baik sebanyak 47 orang sekitar (94,0\%), sebagian kecil yang tingkat pengetahuan cukup baik dan pelaksanaan dalam identifikasi patient safety baik sebanyak 3 orang ( 6,0\%), sebagian besar yang tingkat pengetahuan baik dan pelaksanaan identifikasi dalam patient safety baik sebanyak 10 orang $(71,4 \%)$, yang tingkat pengetahuannya baik dan pelaksanaan identifikasi dalam patient safety cukup baik sebanyak 4 orang $(28,6 \%)$.

Jurnal Kedua, Budaya Keselamatan Pasien Oleh Perawat Dalam Melaksanakan Pelayanan Di Ruang Rawat Inap. Jurnal JIM FKEP Volume III No.4 2018. Menurut hasil dari jurnal tersebut, dapat disimpulkan bahwa frekuensi gambaran budaya keselamatan pasien oleh perawat dalam melaksanakan pelayanan di ruang rawat inap berada pada kategori baik, yaitu sebanyak 65 responden sekitaran $(91 \%)$.

Maka dari hasil perbandingan jurnal - jurnal tersebut, dapat disimpulkan bahwa hubungan tingkat pengetahuan perawat dengan budaya keselamatan pasien di ruang rawat inap memiliki mayoritas dalam kategori yang hampir sama yaitu dalam hubungan tingkat pengetahuan perawat memiliki kategori yang cukup baik dan pelaksanaannya dalam identifikasi patient safety terdapat dalam kategori baik. Sedangkan dengan budaya keselamatan pasien di ruang rawat inap memiliki kategori baik. Dari perbandingan kedua jurnal tersebut, sangatlah penting untuk tercapainya keselamatan pasien di ruang rawat inap, dapat mengurangi angka kecelakaan di tempat kerja, serta menjaga keselamatan dilingkungan Rumah sakit. 


\section{PEMBAHASAN}

1. Hubungan antara Tingkat Pengetahuan Perawat dengan Pelaksanaan Identifikasi dalam Patient Safety

Pendidikan adalah langkah awal untuk melihat kemampuan seseorang. (Notoatmodjo, 2012) menyatakan bahwa hal lain yang dapat mempengaruhi pengetahuan adalah tingkat pendidikan. Semakin tinggi pengetahuan seseorang maka akan semakin baik pula pengetahuan yang dimiliki orang tersebut. Namun perlu ditekankan bahwa seseorang yang berpendidikan rendah tidak berarti mutlak berpengetahuan rendah pula karena kemampuan belajar yang dimiliki juga dapat mempengaruhi pengetahuan, dengan kemampuan belajar yang baik seseorang akan cenderung mendapatkan informasi yang lebih banyak, baik dari orang lain maupun dari media massa. Semakin banyak informasi yang diperoleh maka semakin banyak pula pengetahuan yang didapat. Berdasarkan hasil analisis jurnal, Hubungan Tingkat Pengetahuan Perawat tentang Indentifikasi dalam Patient Safety dengan Pelaksanaannya di Ruang Rawat Inap RSUD SK. Lerik Kupang. Jurnal Ilmiah Keperawatan Stikes Hang Tuah Surabaya Vol.14 No.2 October 2019, didapatkan hampir seluruhnya perawat yang memiliki tingkat pengetahuan yang cukup baik dengan pelaksanaan identifikasi dalam patient safety cukup baik sebanyak 47 orang (92,2\%) lebih dominan dari tingkat pengetahuan yang cukup baik dan pelaksanaan identifikasi dalam patient safety baik sebanyak 3 orang $(23,1 \%)$. (Hughes, 2008) menyatakan bahwa langkah awal memperbaiki pelayanan yang berkualitas adalah keselamatan, sedangkan kunci dari pelayanan bermutu dan aman adalah membangun budaya keselamatan pasien. Menurut Mitchell dalam Hughes (2008), perawat merupakan kunci dalam pengembangan mutu melalui keselamatan pasien. Adanya dukungan dan supervisi kepala ruangan terhadap kinerja perawat pelaksana juga sangat dibutuhkan dalam pelaksanaan identifikasi pasien dan hal ini menjadi salah satu indikator keberhasilan pelaksanaan identifikasi pasien. Hal ini menjadi salah satu indikator keberhasilan pelaksanaan identifikasi pasien. Berdasarkan hasil analisis jurnal tersebut, tingkat pengetahuan baik dengan pelaksanaan identifikasi dalam patient safety baik sebanyak 10 orang $(76,9 \%)$ lebih dominan dari tingkat pengetahuan baik dengan pelaksanaan identifikasi dalam patient safety cukup baik sebanyak 4 orang $(7,8 \%)$. Semakin tinggi tingkat pengetahuan seseorang maka akan semakin baik pula pengetahuan 
yang dimiliki orang tersebut (Notoatmodjo, 2012). (Budiono, 2014)menyatakan bahwa untuk meningkatkan pengetahuan tenaga kesehatan khususnya perawat, hal yang perlu dilakukan yaitu sosialisasi dan pelatihan. Oleh karena itu, perlu meningkatkan pendidikan terutama pada tim kesehatan salah satunya ialah seorang perawat. Seorang perawat perlu meningkatkan pendidikannya ke jenjang yang lebih tinggi dan pentingnya menanamkan budaya safety di lingkungan kerja rumah sakit.

\section{Indikator Budaya Keselamatan yang meliputi; kerja sama, komunikasi,} kepemimpinan, pelaporan, dan respon tidak menghukum terhadap kesalahan

Berdasarkan hasil pembahasan dalam jurnal, Budaya Keselamatan Pasien Di Ruang Rawat Inap Rumah Sakit X Kabupaten Jember. Jurnal IKESMA Volume 11 Nomor 1 Maret 2015. Terdapat penjelasan mengenai indikator budaya keselamatan yang meliputi; kerja sama, komunikasi, kepemimpinan, pelaporan, dan respon tidak menghukum terhadap kesalahan yaitu :

1. Kerja sama

Kerja sama merupakan indikator yang pertama dan utama dari budaya keselamatan pasien. Berdasarkan hasil pembahasan jurnal tersebut, bahwa dalam melaksanakan asuhan keperawatan kepada pasien perawat akan selalu membutuhkan bantuan dari perawat maupun tenaga kesehatan yang lainnya. Bentuk kerjasama tidak hanya berupa saling membantu pekerjaan ketika perawat dihadapkan pada tugas yang sangat banyak dan membutuhkan penyelesaian yang sesegera mungkin, namun juga bisa berupa pembagian tugas berdasarkan kelompok kecil atau tim dalam satu unit ruang rawat inap.

Perawat adalah petugas kesehatan dengan waktu kerja tertinggi yang memberikan 24 jam pelayanan terus menerus, melakukan kolaborasi dengan tim kesehatan lain dan oleh karena hal tersebut dapat menyebabkan risiko terjadinya cedera. Keterlibatan banyak profesi selain tenaga perawat dalam melakukan asuhan keperawatan dapat menimbulkan atau berisiko terjadi cedera jika dilakukan tidak dengan komunikasi dan koordinasi yang tepat, hal itu (cedera) dapat dihindari jika perawat selalu menjaga hubungan baik dengan sesama perawat dan petugas kesehatan lainnya, dan menjaga keharmonisan di lingkungan kerja atau suasana hati untuk mencapai 
pelayanan kesehatan. Hal ini karena dengan adanya kekompakan dalam bekerja sama dan saling berinteraksi untuk mencapai tujuan bersama.

2. Komunikasi

Komunikasi sangatlah penting dalam setiap melaksanakan tugas dalam hal ini adalah melaksanakan asuhan keperawatan pada pasien. Komunikasi yang baik dan benar perlu dilakukan untuk mengkoordinasikan asuhan keperawatan yang melibatkan banyak profesi selain profesi perawat. Perawat memiliki peran yang paling dominan dalam mencegah terjadinya kesalahan dalam pengobatan, termasuk pelaporan insiden, mendidik diri sendiri dan perawat lain tentang penting komunikasi, memberikan rekomendasi untuk perubahan prosedur dan kebijakan serta keterlibatan dalam melakukan identifikasi permasalahan. Kesalahan medis jarang disebabkan oleh faktor kesalahan manusia secara individual, tetapi lebih karena kesalahan pada sistem komunikasi yang menyebabkan terputusnya rantai dalam sistem tersebut. Hal ini menunjukkan pentingnya menjalin komunikasi dengan baik agar informasi yang disampaikan tidak terputus dan tidak mengakibatkan kerugian pada pasien. Informasi tentang keselamatan pasien perlu diketahui oleh semua perawat yang memberikan asuhan keperwatan hal tersebut berfungsi untuk mencegah perawat melakukan tindakan yang dapat menyebabkan cedera pada pasien. Komunikasi adalah kunci sukses berinteraksi dalam kehidupan berorganisasi. Ketika komuniksai efektif, arus informasi dalam organisasi yang dinamis akan berjalan lancar sehingga mempercepat proses tercapainya tujuan organisasi.

3. Kepemimpinan

Pemimpin harus memiliki komitmen yang kuat terhadap keselamatan pasien, sehingga keselamatan pasien menjadi hal yang utama dalam memberikan pelayanan keperawatan. Pimpinan mendorong dan menumbuhkan komunikasi dan koordinasi antar unit dan individu berkaitan dengan pengambilan keputusan tentang keselamatan pasien. Pimpinan mengalokasikan sumber daya yang adekuat untuk mengukur, mengkaji, dan meningkatkan kinerja rumah sakit serta meningkatkan keselamatan pasien. 
Pimpinan mengukur dan mengkaji efektifitas kontribusinya dalam meningkatkan kinerja rumah sakit dan keselamatan pasien. Pemimpin juga harus mampu memotivasi bawahannya, salah satunya dengan pujian. Pujian yang diberikan oleh pemberi kerja pada saat pekerjaan yang selesai dilakukan sesuai dengan prosedur yang ditetapkan akan memberikan motivasi tersendiri untuk perawat.

4. Pelaporan

Indikator pelaporan yang terdapat dalam jurnal tersebut, ialah penerapan budaya keselamatan pasien berada dalam kategori cukup. Perawat diharuskan melaporkan kejadian kesalahan yang tidak disengaja dan kondisi yang mengakibatkan atau berpotensi mengakibatkan cedera yang dapat dicegah pada pasien, yang terdiri dari kejadian tidak diharapkan, kejadian nyaris cedera, kejadian tidak cedera dan kejadian potensial cedera. Melaporkan sebuah kejadian atau insiden keselamatan pasien masih jarang dilakukan atau pun bahkan jika ada pelaporan tentang insiden atau kejadian keselamatan pasien belum ada pelaporan secara resmi. Hal ini disebabkan para perawat takut untuk melaporkan insiden yang terjadi pada pasien karena kesalahan yang dilakukannya. Perawat merasa takut akan hukuman atas kesalahan yang telah ia lakukan saat melakukan asuhan keperawatan. Peran dan fungsi perawat yang salah satunya yaitu peran sebagai peneliti. Informasi yang benar dan jelas yang diperoleh dai sistem pelaporan, asesmen risiko, kajian insiden, dan audit serta analisis, digunakan untuk menentukan solusi.

5. Respon Tidak Menghukum Terhadap Kesalahan

Indikator respon tidak menghukum terhadap kesalahan ini menunjukkan bahwa dimasa yang akan datang pelaporan terhadap insiden keselamatan pasien tidak semata-mata hanya berupa pelaporan insiden keselamatan, namun pelaporan tersebut hendaknya ditindaklanjuti guna memperbaiki kesalahan dan mencari akar permasalahan, tidak untuk menghukum perawat yang melakukan kesalahan atau berpengaruh terhadap penilaian kinerjanya. Belajar dari insiden keselamatan pasien hanya akan berhasil jika setiap permasalahan tidak dilihat sebagai kesalahan individu tetapi harus diperhatikan dengan 
pendekatan sistem dan pemahaman faktor manusia. Sebagaimana diatur dalam Peraturan Menteri Kesehatan Republik Indonesia nomor 755/Menkes/Per/IV/2011 tentang pelaksanaan komite medis di rumah sakit bahwa audit medis dilakukan dengan memprioritaskan semua staf untuk menghilangkan blaming (menyalahkan), naming (menyebut atau mencari siapa yang salah), dan shaming (mempermalukan atau mengakui kesalahan). Untuk mampu belajar dari kesalahan harus ditekankan pada upaya mencari apa yang salah, mengapa kesalahan tersebut dapat terjadi, dan apa yang bisa dilakukan untuk memperbaiki kesalahan.

\section{PENUTUP}

Perawatan Rawat Inap adalah salah satu pelayanan kesehatan di rumah sakit yang dapat diakses oleh pasien yang membutuhkan perawatan intensif. Keragaman dan keteraturan para pelayan jika tidak dikelola dengan baik dapat terjadi keselamatan pasien insiden. Keselamatan pasien di rumah sakit melibatkan partisipasi dari semua petugas kesehatan, terutama pada seorang perawat. Budaya keselamatan adalah bagian dari kesalahan laten terkait dengan manajemen. Indikatornya adalah budaya keselamatan kerja sama, komunikasi, kepemimpinan, pelaporan dan respon tidak menghukum atas kesalahan. Kemudian , adapun tingkat pengetahuan perawat dalam mengupayakan keselamatan pasien di Ruang Rawat Inap, dapat disimpulkan dari hasil analisis jurnal dikategorikan cukup baik. Demikian saran yang diberikan untuk kategori dengan nilai yang cukup baik adalah, kepemimpinan harus selalu mendidik staf tentang keselamatan pasien, selalu mengikuti perkembangan pengetahuan tentang perawatan medis dan keperawatan, membudayakan melaporkan sebuah insiden, menekankan kepada semua staf yang terlibat dalam perawatan pasien bahwa pelaporan insiden tidak mencari kesalahan tetapi untuk mendapatkan solusi. Dan harapan selanjutnya tentang budaya keselamatan pasien adalah tentang hubungan antara budaya organisasi dengan keselamatan pasien atau keselamatan hubungan budaya dengan insiden keselamatan pasien. 


\section{DAFTAR PUSTAKA}

Arini, D. Yuliastuti, C. Lusia, R. (2019). Hubungan Tingkat Pengetahuan Perawat tentang Identifikasi dalam Patient Safety dengan Pelaksanaannya di Ruang Rawat Inap RSUD SK. Lerik Kupang. Jurnal Ilmiah Keperawatan Stikes Hang Tuah Surabaya. Vol.14 No.2.

Bawelle, S., Sinolungan, \& Hamel, R. (2013). Hubungan Pengetahuan dan Sikap Perawat dengan Pelaksanaan Keselamatan Pasien (Pasien Safety) di Ruang Rawat Inap RSUD Liun Kandage Tahuna.E-Jurnal Keperawatan, Vol. 1 No 1, Februari 2017.

Bea, I. F., Pasinringi, S. A., \& Noo, N. B. (2013). Gambaran Budaya Keselamatan Pasien di Rumah Sakit Universitas Hasanudin Tahun 2013, 1-14.

Darliana, D. (2016). Hubungan Pengetahuan Perawat Dengan Upaya Penerapan Patient Safety di Ruang Rawat Inap Rumah Sakit Umum Daerah DR.Zainoel Abidin Banda Aceh. Idea Nursing Journal, VII(1), pp. 61-69.

Herawati,Y. (2015). Budaya Keselamatan Pasien Di Ruang Rawat Inap Rumah Sakit X Kabupaten Jember. Jurnal IKESMA. Volume 11 Nomor 1.

Ngalngola, E. (2012). Gambaran Pengetahuan dan Motivasi Perawat terhadap Penerapan Program Patient Safety di Instalasi Rawat Inap RSUD Daya Makassar Tahun 2012. Jurnal Ners. 7(2), 23-29.

Nivalinda, D; Hartini, M.C \& Santoso, A. (2013). Pengaruh motivasi perawat dan gaya kepemimpinan kepala ruang terhadap penerapan budaya keselamatan pasien oleh perawat pelaksana pada Rumah Sakit Pemerintah di Semarang. Jurnal Manajemen Keperawatan, Vol (1) No(2).

Nurlindawati. Jannah,N. (2018). Budaya Keselamatan Pasien Oleh Perawat Dalam Melaksanakan Pelayanan Di Ruang Rawat Inap. Jurnal JIM FKEP. Volume III No.4.

Simamora, R. H. (2018). Buku ajar keselamatan pasien melalui timbang terima pasien berbasis komunikasi efektif: SBAR. Medan: USUpress. 
Simamora, R. H. (2020). Learning of Patient Identification in Patient Safety Programs Through Clinical Preceptor Models. Medico Legal Update, 20(3), 553-556.

Yulia, Sri, A. Y. H. (2012). Peningkatan Pemahaman Perawat Pelaksana Dalam Upaya Penerapan Keselamatan Pasien Melalui Pelatihan Keselamatan Pasien. Jurnal Keperawatan Indonesia, Volume 15, 8.

Yusuf, M. (2017). Penerapan Patient Safety Di Ruang Rawat Inap Rumah Sakit Umum Daerah Dr . Zainoel Abidin Patient Safety Implementation In Ward Of Dr . Zainoel Abidin General Hospital. Jurnal Ilmu Keperawatan, 5(1), 1-6. 